\title{
Noun Phrases in Imaji Terindah Novel By Sitta Karina: A Generative Transformation Analysis
}

\author{
Rona Almos \\ Fakultas Ilmu Budaya, Universitas Andalas, Indonesia \\ ronaalmos81@gmail.com
}

DOI: 10.20884/1.jli.2021.12.2.4729

\begin{abstract}
Article History:
First Received:

ABSTRACT

$22 / 08 / 2021$

Final Revision:

$29 / 11 / 2021$

Available online:

This article is about noun phrases that basically consists of a noun. The data used in this article is taken from the novel "Imaji Terindah" by Sitta Karina with a generative transformation approach. The theory of generative transformation is a system of rules consisting of a limited set of rules but capable of generating or creating a limited number of sentences. There are three stages followed in this research method, namely the stage of providing data. In this step, the listening method is used. Then in analyzing the data analysis, the author uses the distributional method. And the last stage presenting the results of data analysis. At this stage the author uses a formal method. The characteristic of noun phrases in this novel is the noun as the main element. Noun phrases is functioned the subject, predicate, and object. Based on the characteristics of noun phrases in this novel, the elements of noun phrases are grouped into two types, namely primary elements and modifier elements. In the novel "The most beautiful image" by Sitta Karina, there are many sentences using the 'yang' relator.
\end{abstract}

Keywords: phrases; nouns; the elements; generative transform analysis

\section{INTRODUCTION}

Language is a communication tool used to express human thoughts and feelings. Language cannot be separated from humans, because language always follow every activity. Samsuri said that language is closely related to language users, because language is the most vital tool for human life. Furthermore, Samsuri said that the function of language is as a tool used to form thoughts, feelings, desires, and actions (Samsuri, 1987). Language is also a tool to influence humans. From the description above, it appears that language is the main basis that is most deeply rooted in humans.

Language has a very important role for science, culture and literature. Literature is the language (words or language style) used in books (not everyday language) (Language, n.d.). One example of a literary work is a novel. A novel is a long prose essay that contains a series of a 
person's life with those around him by highlighting the character and nature of each actor (Language, n.d.).

Imaji Teridah is a novel by Sitta Karina (2005). In this article, the author will examine Sitta Karina's novel in the field of linguistics, namely syntax, especially regarding noun phrases.

According to Kinanti (2002), to determine the phrase in a sentence, a researcher should first determine the function of the sentence because according to her understanding a phrase is a grammatical unit consisting of two or more words that does not exceed its function limit or does not have a predicate element

According to Kridalaksana (1993), a noun phrase is endocentric phrase with one main element and that main element is a noun. Furthermore, Kingkin Puput Kinanti explained that noun phrases are phrases formed from noun elements (Kinanti, 2020).

Several previous studies that are relevant to this article include research conducted by Aditiawan, 2020. In his article entitled The Use of Nominal Phrases in the Jawa Pos Newspaper Constructing Nominal Phrases was explained that the forms and functions of noun phrases in the Jawa Pos newspaper, December 3, 2019 edition consisted of nouns + verbs. It was found bahan bakar minyak dan tikus berdasi (fuel oil and a tie rat) have in common occupying the object $(\mathrm{O})$, 3 forms and functions of noun phrases consisting of noun + noun such as motor listrik (electric motor) and rumah tangga (households) having the same function occupying object $(\mathrm{O})$, noun + adjective such as Perguruan Tinggi (university) occupying the subject (S) and jangka panjang (long term) occupy the information (adverb).

Furthermore, Wulandari (2018) in her article entitled "Nominal Phrases with Nominal Attributes in Indonesian" explained that the relationship of meaning between nouns and nouns in noun phrases with noun attributes includes: origin, property, result, form, tools, materials, completeness, object, designation, producer, specialization, mixing, field/specialization, calling, title, brand, type, actor, position, name, determinant/indicator, sound, place, cause, contains, and is related to.

Then (Herwandar \& Piantari, 2017) in their article entitled 'Metonymy and Metaphor in Norm and Exploitation Semantic Types Adjective Value of Noun Phrase Eye in COCA' explained that the types of meaning in norms and exploitation vary with the core of expanding literal meaning to metonymy and metaphor. Conceptual metonymy and conceptual metaphor at the elementary level applied to the noun phrase eye is the perceptual organ side by side as perception and the 
conceptual metaphor of seeing is touching. At the abstract level the conceptual metaphor of thinking, knowing or understanding is seeing.

Furthermore, (Dongalemba, 2018) in his article entitled "External Functions and Categories of Manado Malay Noun Phrases" is explained that the level of syntax external functions is filled by subject, predicate, and adverb. The external category level, noun phrases attached to the predicate function are 11 clauses and noun phrases attached to the predicate function are 11 clauses, and noun phrases attached to adverbs are 4 clauses.

In the article entitled "Determinant Analysis of the Grammatical System of French Noun Phrases in the Textbook "Echo" can be concluded that the elements forming noun phrases (noun and determinant) are obligatory. The types of determinants in French noun phrases are (1) l'article (indéfini/défini), (2) l'adjective (démonstrative, possessive, numeral, indéfini and qualificatif). The meaning contained in each French noun phrase depends on the construction result.

The next research is research conducted by Fiorentina Nispati Winona Lumanauw, Jenny H. Pakasi, and Garryn Ch. Ranuntu. In their article explained that there are 70 noun phrases contained in the five-page article "Grammys 2020: Big Speeches and Emotional Moments", in each noun phrase there are 47 adjectives that function as pre-modifiers. These adjectives are divided into seven types; adjectives that indicate nationality, adjectives that indicate substance, adjectives that indicate color, adjectives that indicate age, adjectives that indicate shape, adjectives that show size, adjectives that show traits. After that, noun phrases containing adjectives were analyzed using a simple diagram diagram tree. The results of the analysis show that each constituent has its own function according to three functions in the structure of the noun phrase: Determiner, Modifier and Head. Thus, it is proven that the function of the adjective phrase is a pre-modifier of the noun phrase head.

Haris Abdul Wasik and Nusarini explained in a journal article entitled " The Use of Nominals in the Harian Tribun Newspaper" that the noun forms used in the Tribune newspaper are basic nouns and derived nouns. First, in derived nouns, we can find nouns formed due to morphological processes, namely affixation, reduplication, and compounding. The affixes that form the derived nouns are affixes per -, peng-, an-, peng-an, per-an, and ke-an. Then the results of reduplication include complete repetition, repetition with affixation, partial repetition, and voice copying repetition. As for the results of compounding, it includes basic compound nouns, affixed compound nouns, graded compound nouns, and equivalent compound nouns. Second, the syntactic behavior of nouns found in the Tribun daily newspaper includes nouns as subject functions, predicate functions, object functions, and complementary functions. 
The article entitled Analysis of the Acceptability Quality Aspects of Noun Phrases in Garuda Indonesia's "Colors" Magazine from English to Indonesian, Yoyok Sabar Waluyo and Laelah Fauziah explained that in the magazine "Warna Garuda Indonesia" published in November 2018 the most common noun phrase found is modified noun phrases. Then, the acceptability quality aspect of this magazine is at a score of 2.7 out of 3 . This means that the translation results are well received by Indonesian readers. The translated phrases can be understood by the readers well.

In contrast to previous studies, in this article the author describes the syntax, especially noun phrases in the novel Imaji Terindah by Sitta Karina by using a generative transformation approach.

Based on the background above the aim of the research is to describe the characteristics of noun phrase in Sitta Karina's Imaji Terindah novel. Analyzing the rules of transformation of noun phrases in Imaji Terindah novel by Sitta Karina.

\section{Generative Transformation}

The theory of generative transformation is not only useful in basic grammatical analysis, but also well known in the field of linguistics and provides important insights in languages that are not easily described by other theories (Suwena, 1997). Generative transformation can deal with language problems that cannot be solved by other theories such as the problem of sentence linkage, active and passive relationships, and ambiguity (Dardjowidjojo, 1987).

The theory applied in this study is an extended standard generative transformation theory. This generative transformation theory is one of the version of the standard theory after 1965, especially that developed by Daly et al (in Suwena, 1997). This version of the theory of generative transformation remains abstract and its application is more practical, so it is quite useful for this paper, which can emphasize the levels of analysis, such as words, phrases, and clauses (Daly, 1981: iii (Suwena, 1997)). Therefore, grammatical functions need to be stated explicitly in syntactic rules. In this case, the sentence does not need to be analyzed into two major parts, namely noun phrases (NP) and verb phrases (VP), but can be analyzed on its parts according to the nature of the language concerned. The application of this theory in noun phrases will be adjusted to the grammar of Sitta Karina's Imaji Terindah novel.

The theory of generative transformation which is also called the theory of grammar transformation of the theory of linguistics (Samsuri, 1987). Generative transformation theory is a system of rules consisting of a limited set of rules but capable of generating or creating a limited 
number of sentences. The rule system can be analyzed into three main components, namely syntactic components, phonological components, and semantic components (Chomsky, 1965). Thus, the grammar must consist of these three main components.

Phrases are grammatical in the form of a combination of two or more words that are not predicative (Kridalaksana, 1993). Noun phrase or phrase in general is one of the topics of conversation in categorization. Categorization or grammatical classification is not limited to a word, but also to other units above it. To determine the class is the same as determining the word class, namely based on syntactic behavior. Kridalaksana states that the noun phrase is a single parent endocentric phrase whose main element is a noun (Kridalaksana, 1993).

A noun phrase is a phrase whose core consists of a noun. This phrase can be in the form of words or groups of words that act as sentence guides, which basically function as noun (Samsuri, 1987). The guiding elements of noun phrases have the same distribution as nouns. In other words, a noun phrase is a modified phrase consisting of a noun as a main and other expansion elements that have a subordinate relationship with the main clause (Kridalaksana, 1993).

Words can combine with one another and form a larger unit called a phrase. The phrases join to form a larger contribution, namely clauses and clauses join to form larger constructions called sentences, and so on. One of the means to study the structure of the constituent parts within the section can be used phrase markers or called diagram diagram trees. Through diagram diagram trees, it is possible to observe the parts of a phrase, clause, and get to the smaller parts (eg words) that are appropriate and appropriate to jointly form larger parts, namely phrases and clauses (Bickford, 1991).

Phrase structure rules are formal rules that are written using symbols or symbols from the constitution of a sentence (clause) of a language. The rule of phrase structure of a language is to provide information about the hoops and symbols that are allowed in the inner structure. This rule will provide an explicit and detailed statement about the diagram tree. With regard to grammatical classes, constituents, and word order so that the diagram tree that is built looks good and not good (Bickford, 1991).

The diagram diagram tree is an appropriate means of explaining the internal hierarchical structure of the sentence generated by the phrase structure rules. A set of diagram diagram trees consists of nodes and branches. A node is a point where two or more lines meet in a diagram tree. The lines connecting the diagram tree are called branches. The topmost of node in the diagram tree is called the branch. The topmost of node in the diagram tree is called the final node and is given a table of specific words. The node that exists between the root loop and the ending loop is called a non-ending loop, which is labile to indicate the syntactic category of the constituents below it. 
The hoops directly above the ending hoops are special non-ending hoops called pre-ending hoops and are labeled according to syntactic categories, such as N, V, Adj which have words below them. Take a look at the diagram diagram tree below.

Picture 1. Noun Phrases Type and Constituent

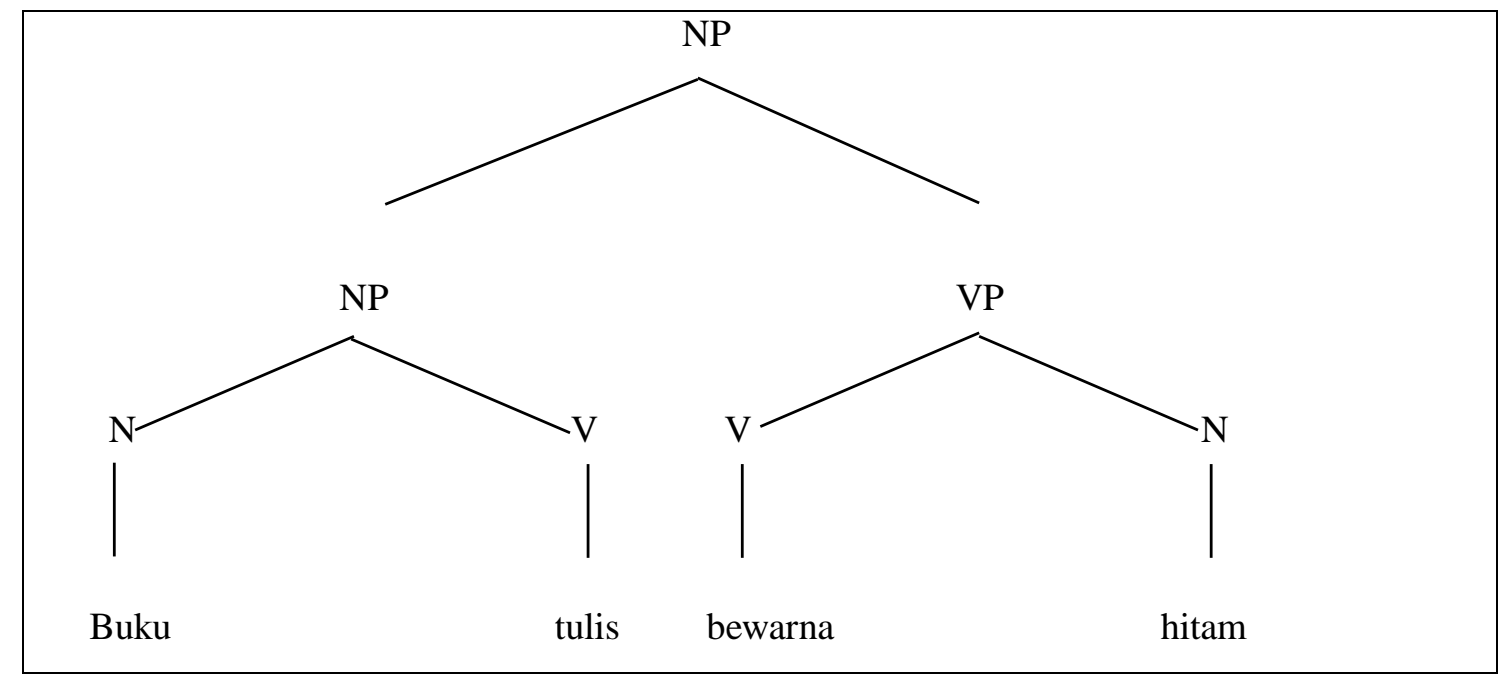

The diagram tree above shows that buku tulis is a constituent of NP type and followed by constituent VP berwarna hitam. Each pre-end hoop is a category that has every lexical element under it.

\section{MATERIALS AND METHOD}

This is a descriptive research since the data being analyzed is in form written data. In doing descriptive research, there are three steps that must be followed, they are, providing data, analyzing data, and presenting the results of data analysis (Sudaryanto, 1993).

The method of providing data in this research is the observing method (Sudaryanto, 1993), or specifically it can be said reading method because the data source in this study is written data. The basic technique used is the tapping technique, namely the implementation of the listening method by tapping the use of the language of a person or several people. In this study, the language that was tapped in the form of writing.

The advanced technique of providing data is non-participant observational technique. This activity is carried out by observing to the use of language without participating in the conversation process. In this technique, researchers are not directly involved in determining the formation and appearance of prospective data. In this technique the researcher reads and understands the contents of the Imaji Terindah novel so that the desired data can be found (Sudaryanto, 1993). 
After collecting the data, then it classified according to research purposes. This means that the researcher reads the novel Imaji Terindah then the researcher sorts out the sentences are which can be counted as the data. This is done to make it easier in analyzing the data.

The next step is the methods and techniques of data analysis. The data analysis method used is the identity method. The identity method is a method which determining tool is part of the language being studied (Sudaryanto, 1993). The technique used in this identity method is diferentiating technique and insertion techniques. The differentiating technique is used to sort out grammatical units starting from the smallest to the largest that can be analyzed (words, phrases, clauses, sentences, and discourse). Furthermore, the technique used is the insertion technique. The insertion technique is a data analysis technique by inserting other linguistic units between the analyzed constructs. The application of this insertion technique to find out the grammatical units in the sentences contained in the novel.

The last procedure performed is the presentation of data analysis. According to Sudaryanto, there are two methods of presenting the results of data analysis, the informal method and the formal method. Informal method is stated in the form of a short, precise, and clear verbal statement. The methods and techniques for presenting the results of the data analysis above can be described, as the formulation in words that are presented in a concise and clear manner (methodologically referred to as the informal method) (Sudaryanto, 1993). Then the formal method is presenting the results of formal data analysis uses signs and symbols.

\section{RESULTS AND DISCUSSION}

As previously discussed, in this section the data from Sinta Karina's Imaji Terindah novel is analyzed based on the problems above, namely describing the characteristics of noun phrases and analyzing the transformation rules of noun phrase rules using generative transformation theory, using diagram diagram trees. Diagram diagram trees, also called phrase markers, are the easiest means of unifying the structure of the constituent parts within the section (Bickford, 1991).

It has been mentioned that a noun phrase is a phrase that consists of a noun as a main element or core which can be expanded with a modifier. In other words, the characteristic of a noun phrase is having noun as a main element (core) and its expansion is a delimiter. These characteristics can be seen in the data below. 


\section{1) Rumah Aki amat homey dan asri (hal,46) .}

Aki's house is very homey and beautiful (p.46).

Sentence (1) consists of a subject in the category of noun phrase filled with the noun rumah $a k i$ and has a predicate in the category of adjective phrase filled with amat homey and asri.

2) Tangan kanan Chris menyentuh meja itu. (hal, 53)

Chris' right hand touched the table. (p. 53)

Sentence (2) consists of a subject in the category of noun phrase which is filled by tangan kanan Chris as noun and has a predicate in the category of verb phrase which is filled yang menyentuh and the object is meja itu.

3) Kedua tangan Aki yang merengkuh pinggangnya (hal, 53).

Both of Aki's hands are embracing her waist (p, 53).

Sentence (3) consists of the subject in the category of noun phrase filled with the noun of tangan Aki which has the second numeral delimiter by having the predicate in the category of verb phrase which is filled with yang merengkuh and the object is pinggangnya.

4) Chris berbicara diponselnya yang terhimpit diantara bahu dan telinga kanannya (hal, 67).

Chris is talking on his cell phone which is squeezed between his right shoulder and ear (p, $67)$.

Sentence (4) consists of a subject that is filled by Chris with a predicate in the category of a verb phrase which is filled by verb berbicara that has a noun delimiter diponselnya and is followed by an object that is in the category of a noun phrase yang terhimpit di antara bahu dan telingan kanannya.

5) Mama Papa kamu sedang membeli makanan di kafetaria (hal, 68)

Your Mom and Dad are buying food in the cafeteria (p, 68)

Sentence (5) consists of a subject in the noun phrase category, filled with mama papa kamu have a predicate in the verb phrase category, filled with the verb membeli which has a sedang as adverb delimiter, the object is makan and followed by a place description, namely di kafetaria. 
6) Anak kecil itu membuat Chris dan Aki tersentak.

The little boy made Chris and Aki flinch.

Sentence (6), the subject is in the noun phrase category Anak kecil itu, the predicate makes up and is followed by the object in the noun phrase category, which is filled in by the nouns Chris dan Aki which have the verb tersentak as delimiter.

After classifying the data, the rules for generative transformation in Sitta Karina's novel Imaji Terindah are found in 10 sentences. The following is explained one by one.

Data 1:

Margo mengacungkan tangan kanannya yang masih memegang kunci ban (Karina, 2005: 11).

(Margo raised his right hand which was still holding the tire wrench (Karina, 2005: 11)).

Picture 2. Diagram Diagram tree of Data (1)

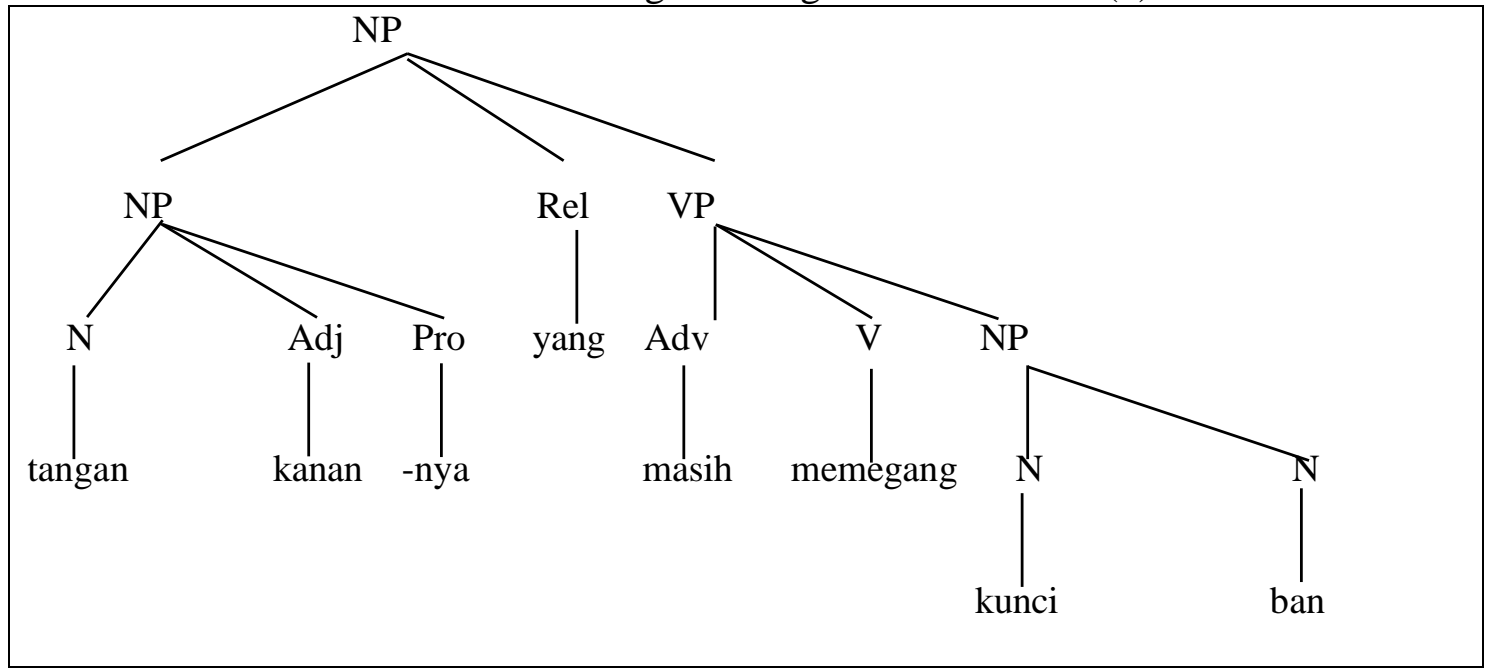

The diagram tree above shows that tangan kanannya is a constituent of the NP type, followed by the Relator yang, and the VP constituent masih memegang, then VP has the constituent root of kunci ban NP. 


\section{Data 2:}

Pandangan matanya tersilaukan oleh cahaya mentari yang langsung menghantam wajah cutenya yang cenderung berstruktur tegas (Karina, 2005: 13).

(His eyes were dazzled by the sunlight that directly hit his cute face which tends to be firm in structure (Karina, 2005: 13).

Picture 3. Diagram Diagram tree of Data (2)

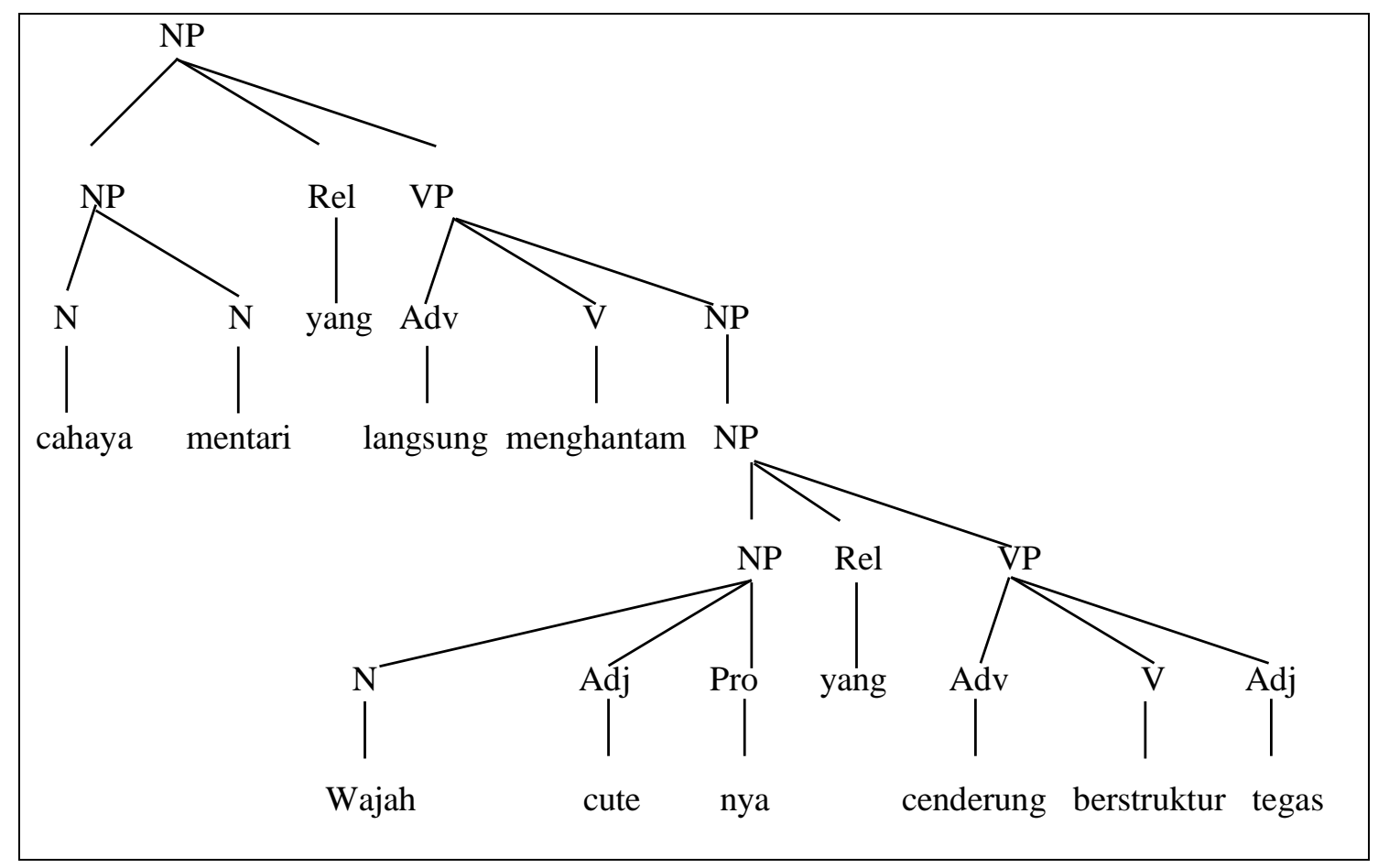

The diagram tree above shows that the strands cahaya matahari are constituents of the NP, followed by the Relator yang, and the VP constituents langsung menghantam, then the VP constituents have NP roots, indicating that the wajah cute strands of the NP constituents are followed by the Relators yang and the VP constituents cenderung berstruktur tegas.

Data 3:

Tiba-tiba Chris tertarik untuk membuka kancing penutup organizer yang sepertnya terbuat dari fine leather (Karina, 2005: 27).

(Suddenly Chris was interested in opening the buttons on the organizer cover which seemed to be made of fine leather (Karina, 2005: 27)). 
Picture 4. Diagram Diagram tree of Data (3)

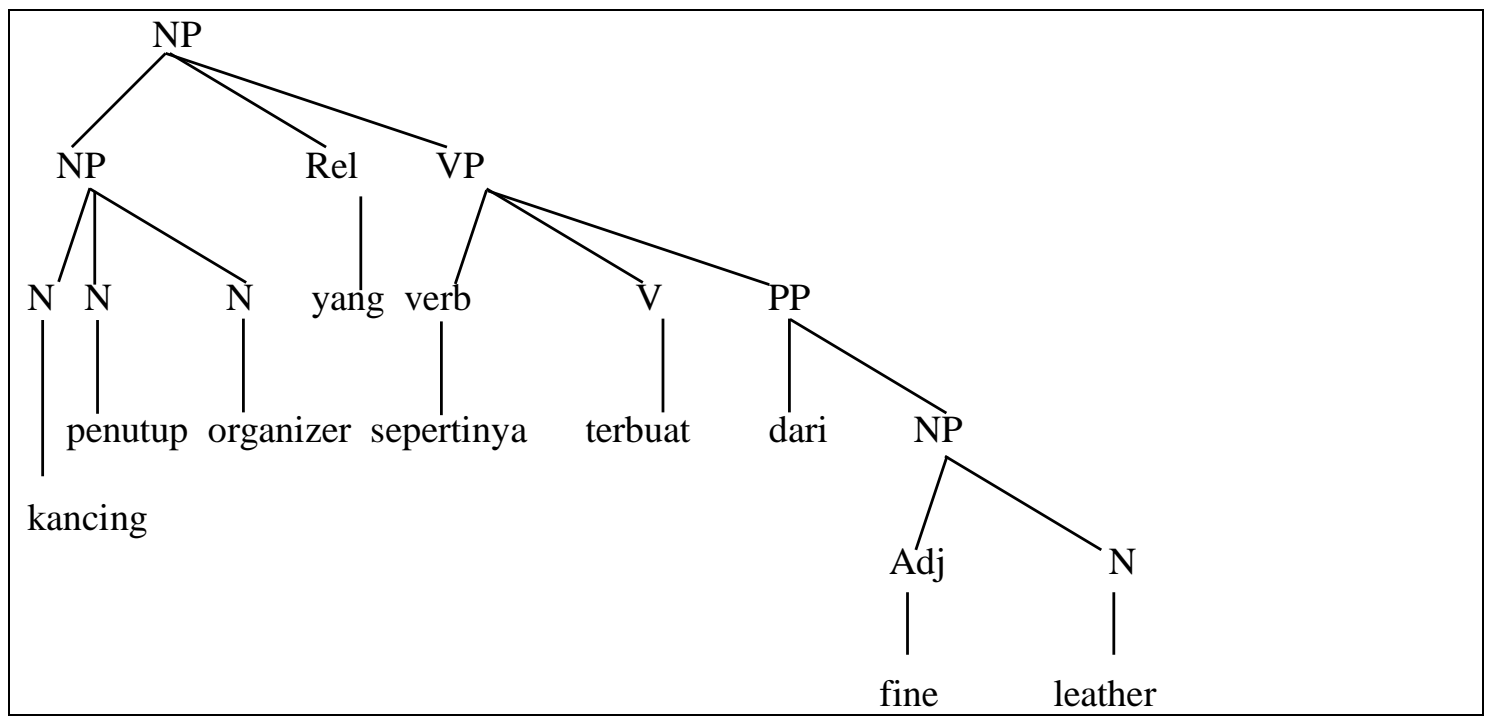

The diagram tree above shows that kunci penutup organizer is a constituent of the NP, followed by the Relator yang and the constituent VP sepertinya terbuat dari, then VP has NP roots indicating that wajah cutenya strands of the NP constituent are followed by the Relator yang and the constituents cenderung berstruktur tegas.

Data 4:

Kianti jadi melangkah keluar dari WC ketika mendengar suara tinggi yang tidak dikenalnya itu (Karina, 2005: 31).

(Kianti stepped out of the toilet when she heard the unfamiliar high voice (Karina, 2005: $31)$ ).

Picture 5. Diagram Diagram tree of Data (4)

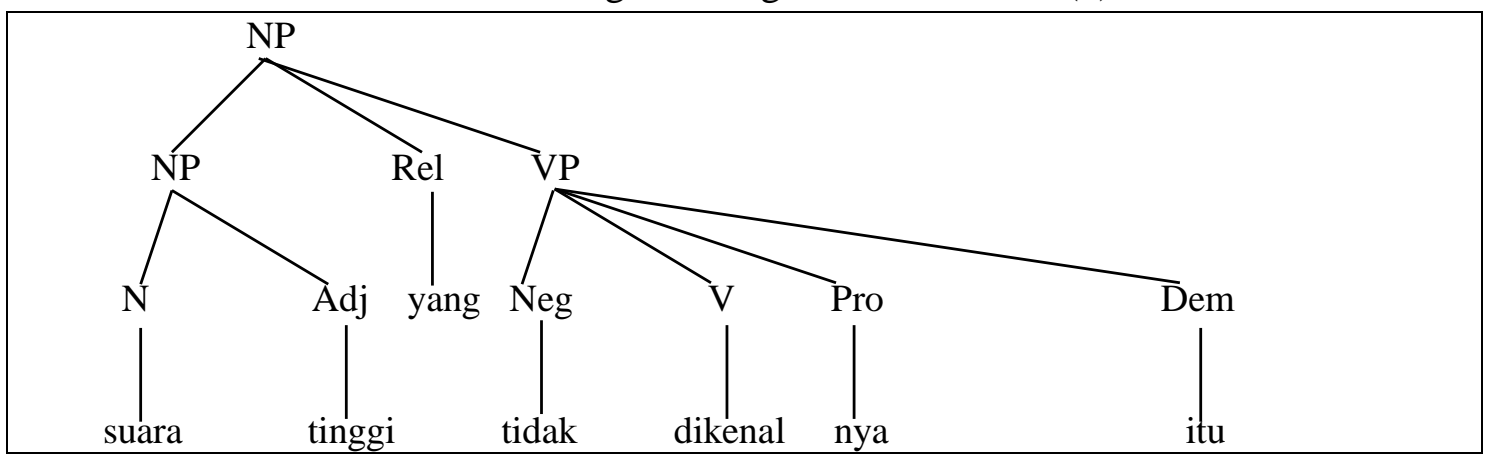

The diagram tree above shows that the suara tinggi strands are constituents of the NP followed by the Relator yang and the VP constituent tidak dikenalnya. 


\section{Data 5:}

"Iya, aki sendirian", Aki berfikir sejenak, berusaha merekayasa cerita yang dapat menciptakan rasa tenang temporer bagi Ayah (Karina, 2005: 40).

("Yes, I'm alone", Aki thought for a moment, trying to create a story that could create a temporary sense of calm for Dad (Karina, 2005: 40)).

Picture 6. Diagram Diagram tree of Data (5)

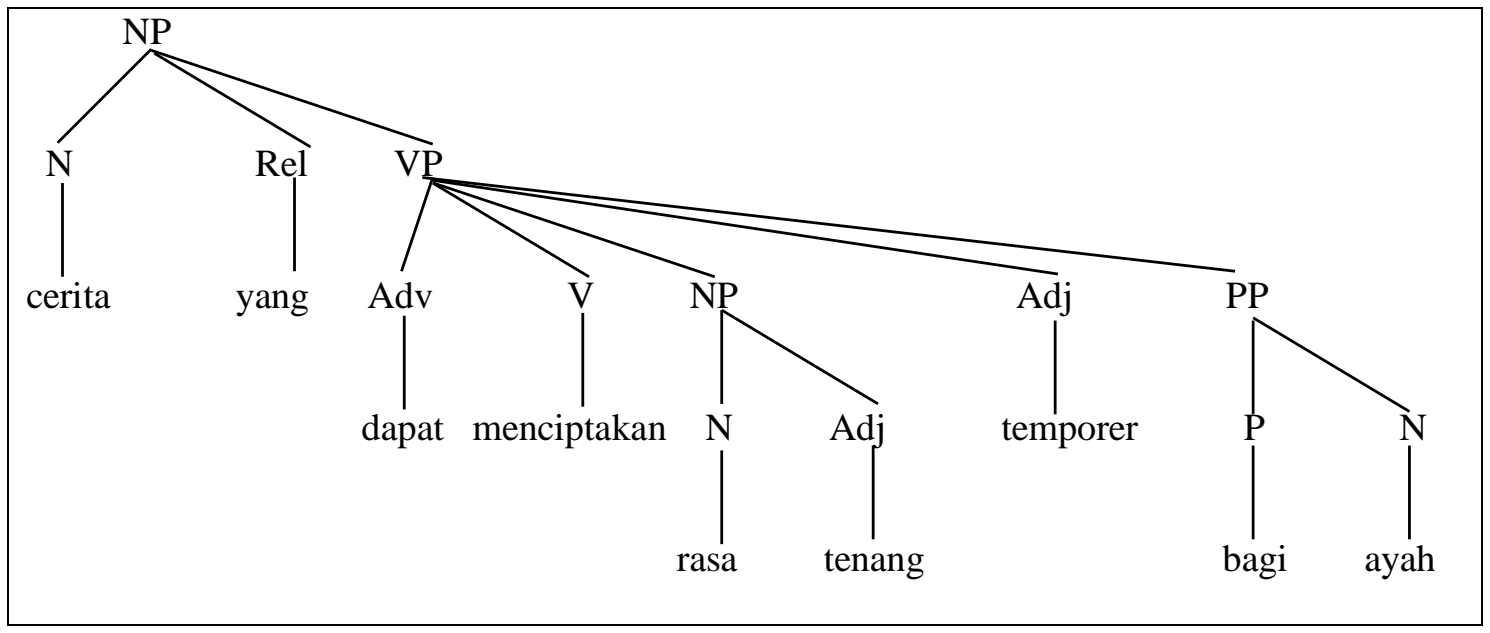

The diagram tree above shows that cerita yang which is a constituent of NP is followed by the Relator yang and the constituent VP dapat menciptakan, temporary adjectives, then VP has the roots of NP rasa tenang and PP bagi ayah.

Data 6:

Semakin ia mendekati lantai atas, semakin keras suara musik yang tadinya terdengar sayup-sayup olehnya (Karina, 2005: 46).

(The closer he got to the top floor, the louder the sound of the music he had previously heard (Karina, 2005: 46)).

Picture 7. Diagram Diagram tree of Data (6)

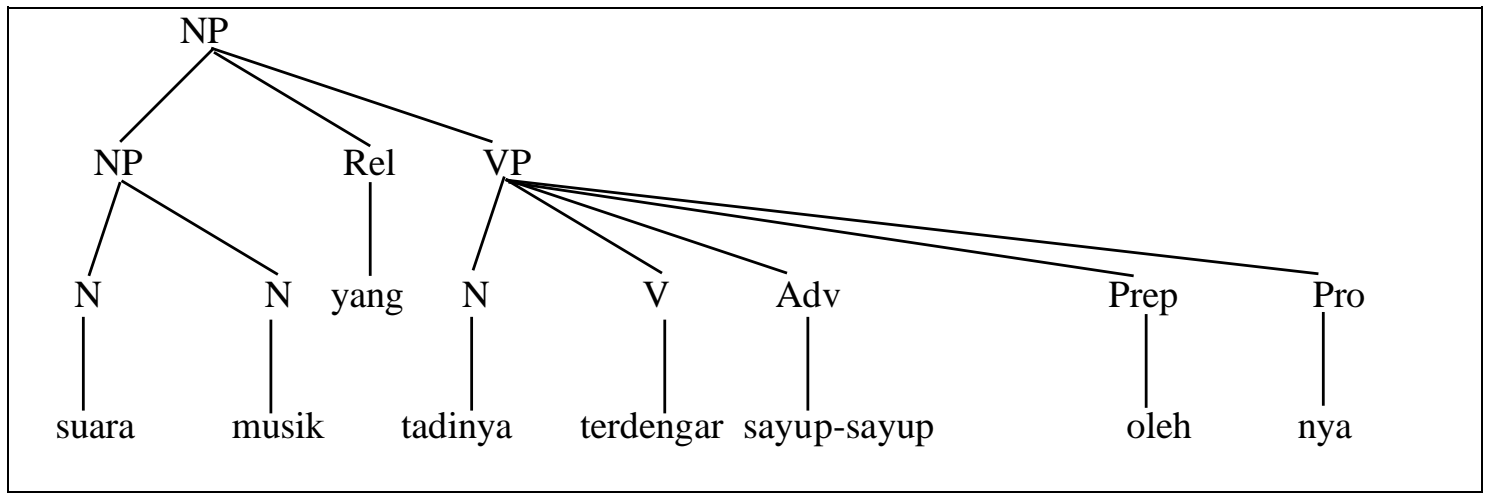


The diagram tree above shows that the strings of suara musik are constituents of the NP followed by the Relator yang and the VP constituents terdengar sayup-sayup olehnya.

Data 7:

Chris memberanikan diri menatap mata bening yang nampak khawatir itu (Karina, 2005: 51).

(Chris dared to look into those clear eyes that looked worried (Karina, 2005: 51)).

Picture 8. Diagram Tree of Data (7)

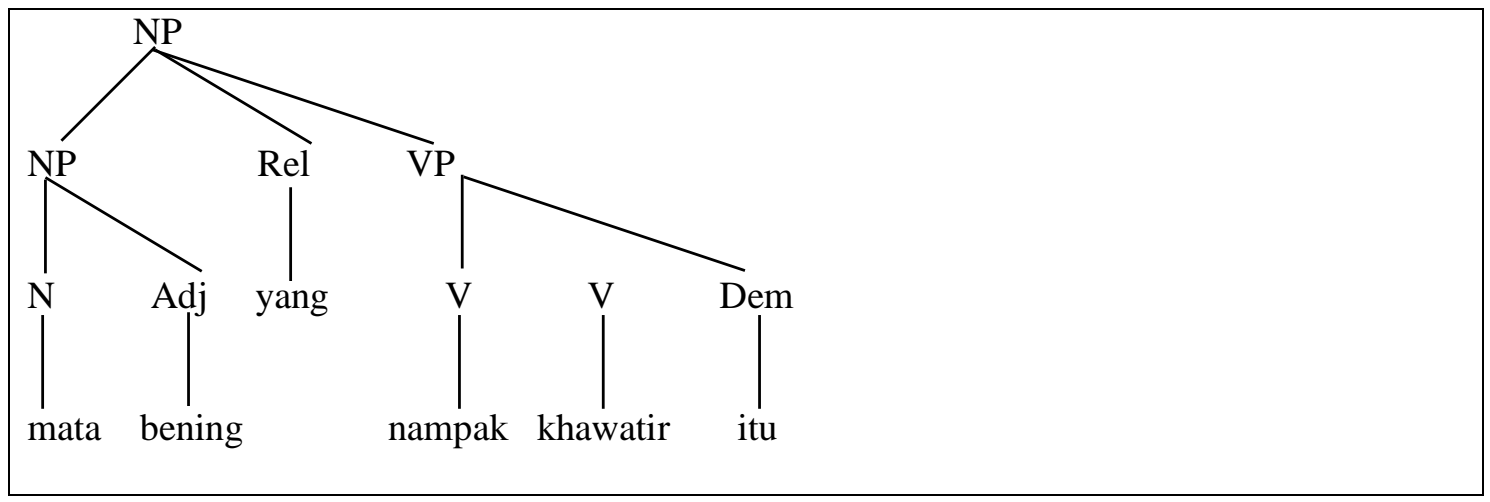

The diagram tree above shows that the mata bening strands are constituents of the NP followed by the Relator yang and the VP constituent Nampak khawatir itu.

Data 8:

Aki dapat melihat Tokyo Tower yang berkilau cantik di kelilingi mandian beribu cahaya lampu gedung di sekitarnya (Karina, 2005: 61).

(Aki can see the Tokyo Tower which sparkles beautifully surrounded by a bath of thousands of lights from the surrounding buildings (Karina, 2005: 61)).

Picture 9. Diagram Tree of Data (8)

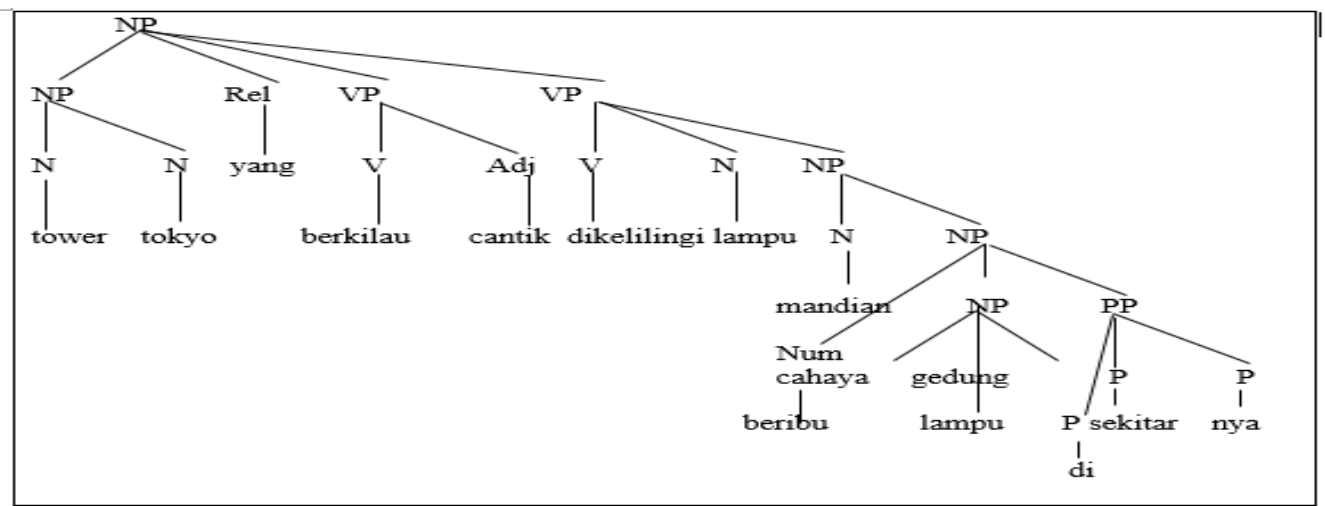


The diagram tree above shows that the tokyo tower strands are constituents of NP followed by Relator yang, the VP constituents berkilau cantik and the VP constituents dikelilingi, then VP is rooted NP mandian, then NP has NP roots consisting of Num beribu, NP cahaya lampu Gedung and PP disekitarnya.

Data 9:

Tiga minggu yang lalu, selain hari berkenalan awal mereka, juga merupakan momen dimana ia 'menembak Aki', dan Aki menolaknya (Karina, 2005: 65).

(Three weeks ago, apart from the day of their initial acquaintance, was also the moment he 'shot Aki', and Aki rejected her (Karina, 2005: 65)).

Picture 10. Diagram Tree of Data (9)

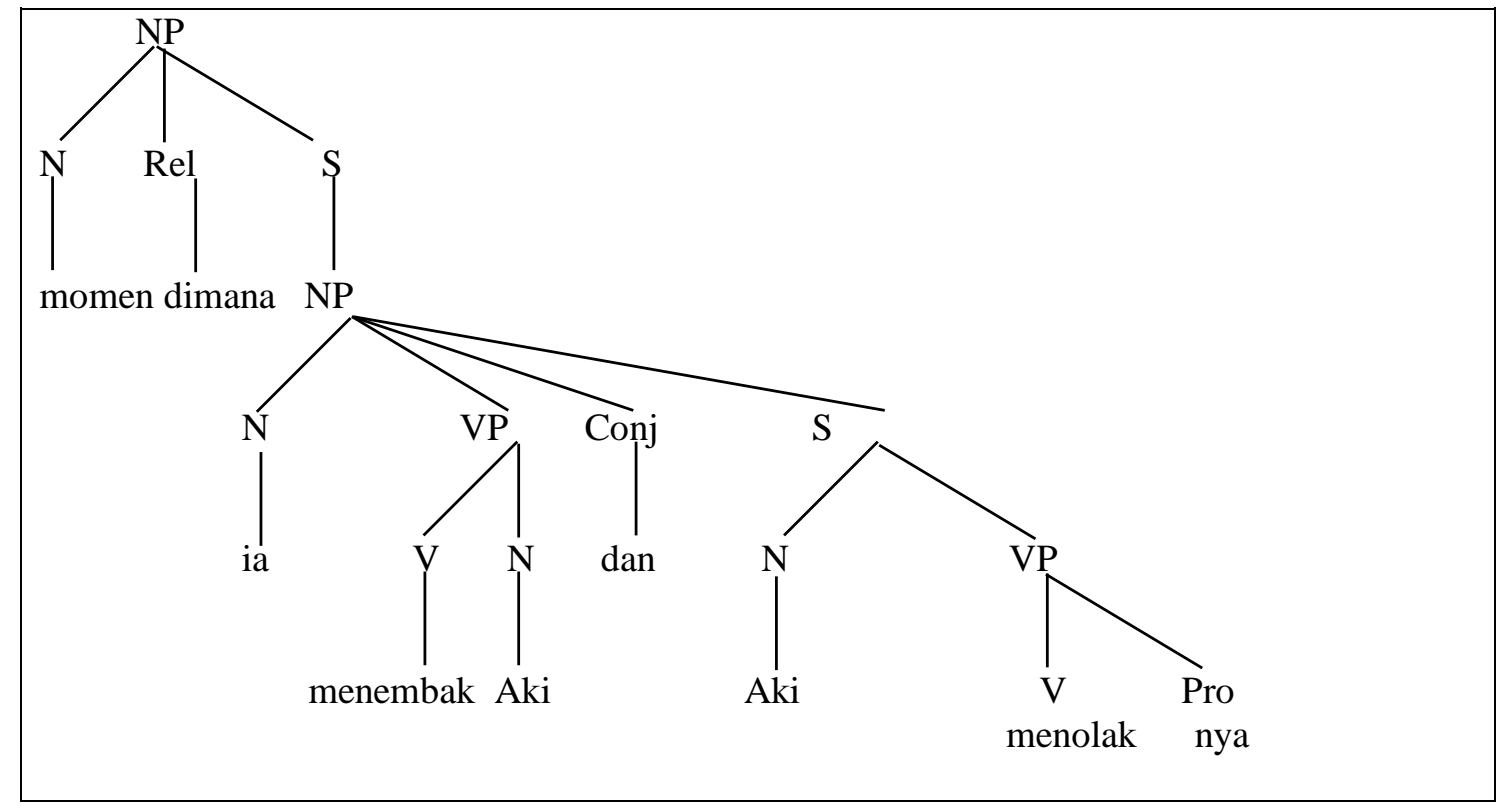

The diagram tree above shows that momen is a constituent of NP type followed by the Relator dimana, $\mathrm{S}$ is rooted in NP which consists of the noun ia, VP menembak Aki, Conj and, then $\mathrm{S}$ which is rooted again to be $\mathrm{N}$ Aki and VP menolaknya. 
Data 10:

Chris berbicara penuh kecemasan di ponselnya yang terhimpit di antara bahu daan telinga kanannya (Karina, 2005: 67).

(Chris talks anxiously on his cell phone which is wedged between his shoulder and right ear (Karina, 2005: 67)).

Picture 11. Diagram Tree of Data (10)

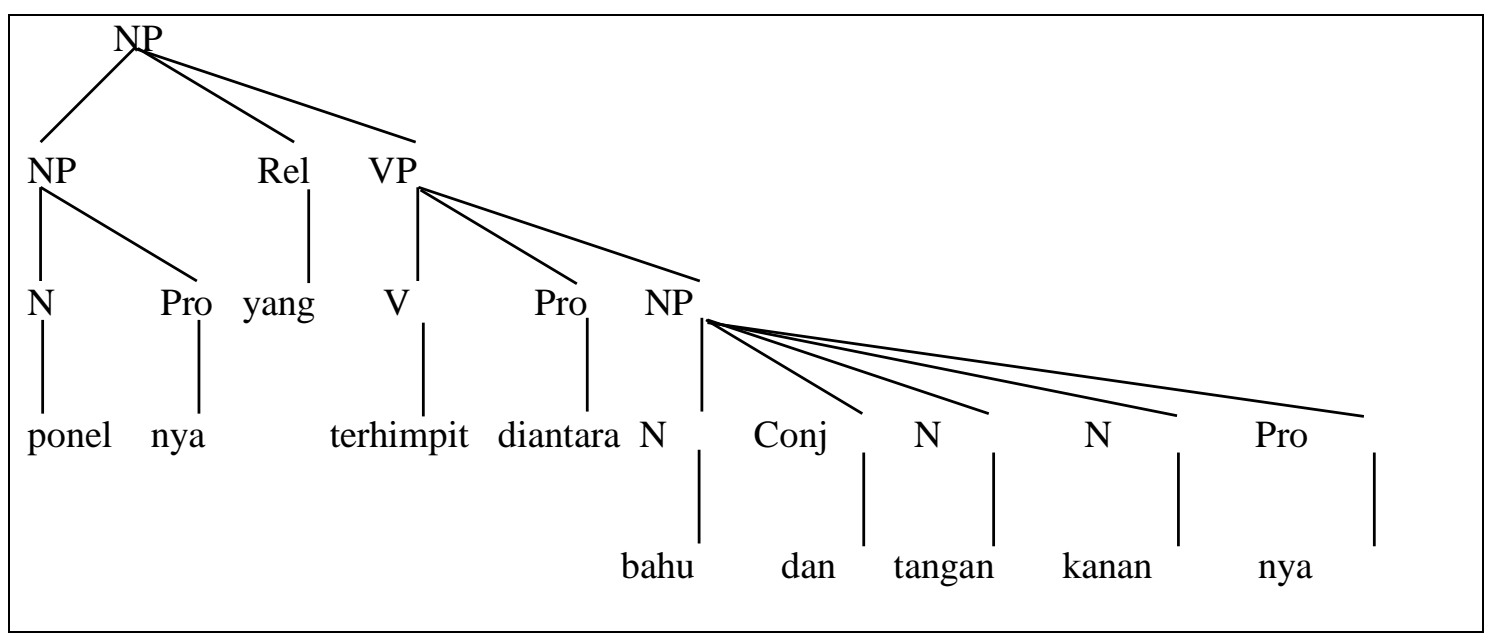

The diagram tree above shows that ponselnya is a constituent of the NP type followed by the Relator yang, and the VP terhimpit diantara, then the VP is rooted in the NP bahu dan tangan kanannya.

\section{CONCLUSION}

Based on the discussion above, the following conclusion can be drawn: First; The characteristic of noun phrases in Imaji Terindah Novel by Sitta Karina is noun as the main element. The noun phrase in the novel is functioned as the subject, predicate, and object. Second; Based on the characteristics of the noun phrases in the novel Imaji Terindah by Sitta Karina, the elements of the noun phrases are grouped into two, the main element and the modifier element.

This paper has described and provided an explanation of noun phrases in the novel Imaji Terindah, but it seems that it has not been able to provide an understanding of various aspects and is still far from what is expected. It is also realized that there are many gaps here and there that are contained in this paper.

There are many things that have not been revealed in the subject of this discussion, and it seems that this paper only reveal the small parts of language phenomenon. Therefore, this research 
needs to be continued thoroughly, even though there is no complete term in studying something. At least further discussion can be deeper from what have been done by the researcher.

\section{ACKNOWLEDGEMENT}

Thank you to Universitas Andalas Research and Service Institute for supporting this research. Thank you also to, Department of Literature Minang, Faculty of Cultural Sciences, Universitas Andalas, who has provided assistance and facilities in this research.

\section{REFERENCES}

Aditiawan, R. T. (2020). Penggunaan Frasa Nomina dalam Surat Kabar Jawa Pos: Kontruksi Frasa Nomina. Belajar Bahasa, 5(2), 221-233. http://jurnal.unmuhjember.ac.id/index.php/BB/article/view/3243.

Badriyah W. (2018). Frasa Nomina Beratribut Nomina dalam Bahasa Indonesia. Jurnal Ilmiah Edikasi Dan Sosial, 9(1), 14-21. http://jiesjournal.com/index.php/jies/article/view/120.

Bahasa, P. (n.d.). Kamus Besar Bahasa Indonesia. https://kbbi.web.id/uang.

Bickford, J. A. (1991). Course In Basic Gramatical Analisys. Tucson AZ.

Chomsky, N. (1965). Aspects. Of The Theory Of Syntax. London: Mit Press.

Dardjowidjojo, S. (1987). Linguistik: Teori dan Terapan. Jakarta: Arca.

Dongalemba, R. M. (2018). Fungsi Eksternal dan Kategori Frase Nomina Bahasa Melayu Manado. Kajian Linguistik, 6(1), 39-51. https://doi.org/https://doi.org/10.35796/kaling.6.1.2018.24781.

Herwandar, R., \& Piantari, L. L. (2017). Metonimia dan Metafora dalam Norma dan Eksploitasi Tipe Semantis Adjektiva Value Frasa Nomina Eye pada Coca. Jurnal Al Azhar Indonesia Seri Humaniora, 4(79-83). https://jurnal.uai.ac.id/index.php/SH/article/view/262.

Karina, S. (2005). Imaji Terindah. Terrentbooks.com.

Kinanti, K. P. (2020). Frasa Nomina Atributif dalam Bahasa Jawa Dialek Jawa Timur. Linguistika, 4(2), 95-104. https://doi.org/http://doi.org/10.25273/linguista.v4i2.6494.

Kridalaksana, H. (1993). Kamus Linguistik. Jakarta: Pt Gramedia Pusat Utama.

Samsuri. (1987). Analisis Bahasa. Jakarta: Erlangga.

Sudaryanto. (1993). Metode dan Aneka Teknik Analisis Bahasa.Yogyakarta: Duta Wacana University Press.

Suwena, I. K. (1997). "Frasa Nomina Bahasa Bali (Suatu Analisis Transformasi Generatif). Universitas Hasanuddin. 